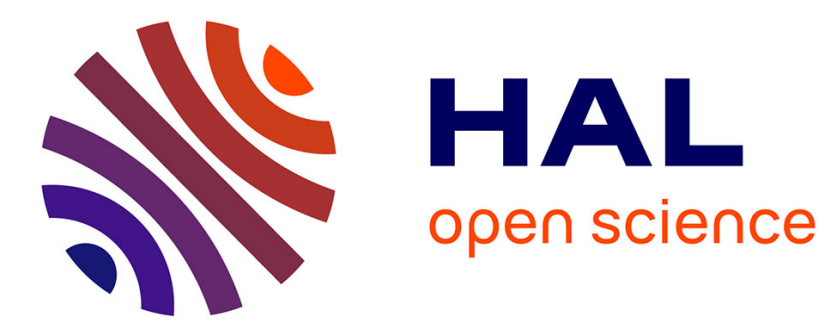

\title{
Lithium insertion/deinsertion of boron doped graphitic carbons synthesized by different procedure
}

\author{
E. Frackowiak, K. Kierzek, G. Lota, J. Machnikowski
}

\section{To cite this version:}

E. Frackowiak, K. Kierzek, G. Lota, J. Machnikowski. Lithium insertion/deinsertion of boron doped graphitic carbons synthesized by different procedure. Journal of Physics and Chemistry of Solids, 2009, 69 (5-6), pp.1179. 10.1016/j.jpcs.2007.10.091 . hal-00509511

HAL Id: hal-00509511

https://hal.science/hal-00509511

Submitted on 13 Aug 2010

HAL is a multi-disciplinary open access archive for the deposit and dissemination of scientific research documents, whether they are published or not. The documents may come from teaching and research institutions in France or abroad, or from public or private research centers.
L'archive ouverte pluridisciplinaire HAL, est destinée au dépôt et à la diffusion de documents scientifiques de niveau recherche, publiés ou non, émanant des établissements d'enseignement et de recherche français ou étrangers, des laboratoires publics ou privés. 


\section{Author's Accepted Manuscript}

Lithium insertion/deinsertion of boron doped graphitic carbons synthesized by different procedure

E. Frackowiak, K. Kierzek, G. Lota, J. Machnikowski

PII: S0022-3697(07)00682-8

DOI:

Reference: doi:10.1016/j.jpcs.2007.10.091 PCS 5272

To appear in:

\section{Journal of Physics and} Chemistry of Solids

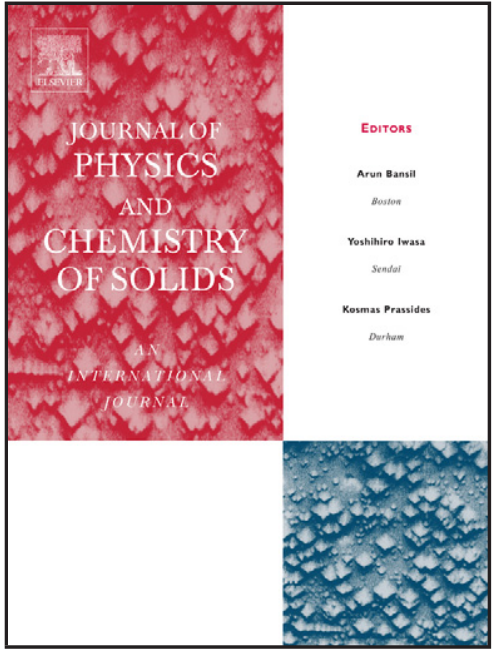

www.elsevier.com/locate/jpcs

Received date: $\quad 30$ June 2007

Revised date: 19 October 2007

Accepted date: $\quad 30$ October 2007

Cite this article as: E. Frackowiak, K. Kierzek, G. Lota and J. Machnikowski, Lithium insertion/deinsertion of boron doped graphitic carbons synthesized by different procedure, Journal of Physics and Chemistry of Solids (2007), doi:10.1016/j.jpcs.2007.10.091

This is a PDF file of an unedited manuscript that has been accepted for publication. As a service to our customers we are providing this early version of the manuscript. The manuscript will undergo copyediting, typesetting, and review of the resulting galley proof before it is published in its final citable form. Please note that during the production process errors may be discovered which could affect the content, and all legal disclaimers that apply to the journal pertain. 


\section{Lithium insertion/deinsertion of boron doped graphitic carbons synthesized by different procedure}

E. Frackowiak ${ }^{1 *}$, K. Kierzek ${ }^{2}$, G. Lota $^{1}$, J. Machnikowski ${ }^{2}$

${ }^{1}$ Poznan University of Technology, ul. Piotrowo 6, 60-965 Poznan, Poland

${ }^{2}$ Wroclaw University of Technology, ul. Gdanska 7/9, 50-344 Wroclaw, Poland

* To whom all correspondence should be addressed

Tel : 48616653632

Fax : 48616652571

E-mail : Elzbieta.Frackowiak@put.poznan.pl 


\begin{abstract}
The lithium insertion/deinsertion behaviour for a series of pure and boron doped graphites prepared from anthracene oil-derived pitch has been studied. Materials treated with boron were pitch-coke and graphitic carbon produced by heat-treatment at $1000^{\circ} \mathrm{C}$ and $2900^{\circ} \mathrm{C}$, respectively. The powdered samples were mixed with $2 \mathrm{wt} \%$ of nanocrystalline boron and annealed at $2300^{\circ} \mathrm{C}$ for $0.5 \mathrm{~h}$ under argon. Additionally, posttreatment of samples in hydrogen at $700^{\circ} \mathrm{C}$ for $1 \mathrm{~h}$ was applied. XRD analysis was performed. Lithium intercalation/deintercalation was monitored using voltammetry and galvanostatic methods. The results show that boron is very effective catalyst of pitchcoke graphitization during heat-treatment at $2300^{\circ} \mathrm{C}$. When added to graphitic carbon, boron induces slight improvement of structural ordering which has been established by preceding heat-treatment at $2900^{\circ} \mathrm{C}$, but the final effect is inferior to that of heattreatment at $3100^{\circ} \mathrm{C}$ without boron. Boron seems to have no positive effect on lithium insertion, whatever the procedure is used. For all the graphitized materials lithium insertion/deinsertion occurs within a narrow potential range $(0-0.5 \mathrm{~V})$ with reversible capacity $\mathrm{X}_{\text {rev }}$ between 0.75 and 0.83 (where $\mathrm{X}$ stands for Li insertion degree in the $\mathrm{Li}_{\mathrm{X}} \mathrm{C}_{6}$ compound, $\mathrm{X}=1$ corresponds to $372 \mathrm{mAh} / \mathrm{g}$ ). Post-treatment of graphitic materials in hydrogen at $700^{\circ} \mathrm{C}$ has a profitable effect on lithium insertion/deinsertion giving the formation of stable passivating layer at first cycle and a decrease of irreversible capacity. Graphite produced by heat-treatment at $2900^{\circ} \mathrm{C}$ followed by treatment in hydrogen gives most promising electrochemical characteristics $\left(\mathrm{X}_{\mathrm{rev}}=0.83\right.$ and $\left.\mathrm{X}_{\mathrm{irr}}=0.10\right)$.
\end{abstract}

Keywords: A. inorganic compounds, C. X-ray diffraction D. electrochemical properties 


\section{Introduction}

Theoretical considerations suggest that the presence of boron substituted for carbon in the lattice should be beneficial for lithium insertion/deinsertion behaviour of carbon material. It is expected that boron possessing one electron less than carbon can locally modify an electronic structure increasing its electron acceptor character. However, due to various side effects associated with boron doping this assumption has not found a clear experimental confirmation, despite several attempts [1-3].

In the present work we study the lithium insertion/deinsertion characteristics for a series of pure and boron doped graphitic carbons obtained by different procedure.

\section{Experimental}

The materials for the synthesis of boron doped carbons were produced by heat treatment of anthracene oil derived pitch at $1000^{\circ} \mathrm{C}$ and $2900^{\circ} \mathrm{C}$. The powdered samples were mixed with $2 \mathrm{wt} \%$ of nanocrystalline boron and annealed at $2300^{\circ} \mathrm{C}$ for $0.5 \mathrm{~h}$ under argon. Post-treatment in hydrogen at $700^{\circ} \mathrm{C}$ for $1 \mathrm{~h}$ was applied to remove some chemisorbed oxygen and to saturate possible dangling bonds. Respective boron-free graphites were used as reference materials.

Powder X-ray diffractograms were recorded with a Philips PW 3710 diffractometer using $\mathrm{Ni}$ radiation with graphite monochromator. The interlayer distance $\mathrm{d}_{002}$ was measured from the maximum of the (002) line. The apparent crystallite height $L_{c}$ was determined from the width of the (002) band and the crystallite diameter $L_{a}$ from the (10) or (110) bands. The $L_{112}$ parameter was calculated from the width of the (112) band. The electrochemical $\mathrm{Li}$ intercalation/deintercalation was performed on pellets prepared by mixing and pressing $85 \%$ of carbon, $5 \%$ of acetylene black and $10 \%$ of PVDF and 
mounted in a Li/carbon cell (Swagelok ${ }^{\circledR}$ system). Voltammetry $(0.05 \mathrm{mV} / \mathrm{s})$ and galvanostatic $(20 \mathrm{~mA} / \mathrm{g})$ experiments were performed using a multichannel potentiostat/galvanostat Mac Pile II (Biologic, France).

\section{Results and discussion}

Optical texture of raw material, i.e. anthracene oil-derived pitch coke P-1 is shown in Fig. 1. Flow type anisotropy is well observed in this image. From this material two series of samples have been prepared where boron ( $2 \mathrm{wt} \%$ ) was introduced thermally at $2300^{\circ} \mathrm{C}$ either into coke prepared at $1000^{\circ} \mathrm{C}$ or into previously graphitized carbon at $2900^{\circ} \mathrm{C}$.

The materials graphitized using different procedures were assessed in terms of structural ordering using XRD analysis. Structural parameters of the graphitic carbons and boronated samples are shown in Table 1 . It can be seen that boron independently of the form used (amorphous boron $\mathrm{B}_{\mathrm{a}}$, nanocrystalline boron $\mathrm{B}_{\mathrm{c}}$ or as a compound $\mathrm{B}_{4} \mathrm{C}$ ) is at the origin of slight improvement of structural ordering, however, the final effect is inferior to that of heat-treatment at $3100^{\circ} \mathrm{C}$ without boron.

Electrochemical characteristics (galvanostatic and voltammetry) allowed to estimate a degree of reversible lithium insertion $\mathrm{X}_{\text {rev }}$ as well as irreversibly stored part of lithium $\mathrm{X}_{\text {irr. }}$ Irreversible capacity $\mathrm{X}_{\text {irr }}($ where $\mathrm{X}=1$ for the charge of $372 \mathrm{mAh} / \mathrm{g}$ ) is a difference between the Li amount inserted during the first reduction process and lithium removed during the first oxidation cycle. Reversible capacity $\mathrm{X}_{\mathrm{rev}}$ corresponds to the lithium amount inserted/deinserted during subsequent cycles. For all the graphitized materials lithium storage occurs within a narrow potential range $(0-0.5 \mathrm{~V})$ with reversible capacity $\mathrm{X}_{\text {rev }}$ between 0.75 and 0.83 . Post-treatment of graphitic materials in hydrogen 
at $700^{\circ} \mathrm{C}$ has a profitable effect on lithium insertion/deinsertion. This is reflected mostly by a decrease of irreversible capacity and the formation of stable passivating layer (solid electrolyte interphase SEI) at first and subsequent cycles. For observation of SEI formation and the detailed qualitative analysis of insertion/deinsertion process, voltammetry characteristics at a slow scan rate of potential $(0.05 \mathrm{mV} / \mathrm{s})$ were especially adapted. Even if an essential insertion/deinsertion process proceeds in the narrow range of voltage (0-0.5 V vs Li) two significant peaks can be observed on voltammetry characteristics during de-intercalation suggesting existence of two domains where different energy is necessary for lithium extraction.

Galvanostatic intercalation/deintercalation into graphitic carbon obtained by heattreatment at $2900^{\circ} \mathrm{C}$ followed by treatment in hydrogen at $700^{\circ} \mathrm{C}(\mathrm{P}-1-2900 \mathrm{H})$ gives most promising electrochemical characteristics, i.e. high reversible capacity $\mathrm{X}_{\mathrm{rev}}=0.83$ and the lowest irreversible capacity $\mathrm{X}_{\mathrm{irr}}=0.10$. It is noteworthy that stable SEI is already formed during the first cycle. Such characteristic has been presented in Fig. 2. On the other hand, it is well seen that the sample $(\mathrm{P}-1-2900 / \mathrm{B}-2300 \mathrm{H})$ with $2 \%$ of boron (Fig. 3) gives an increase of irreversible capacity with cycling which is unwanted phenomenon $\left(X_{\text {irr. }}=0.2\right)$ whereas reversible capacity remains the same $X_{\text {rev }}=0.83$. For all the boron doped samples their characteristics of lithium insertion/deinsertion are not in comparison to non-doped samples.

\section{Conclusion}

The effect of electron acceptor properties of boron substituted for carbon in graphitic carbons is negligible. On the other hand, presence of boron accelerates a graphitization process. Lithium insertion is rather determined by structural organization of carbon than 
its electron properties modified with boron. Treatment by hydrogen slightly reduces irreversible capacity being at the origin of more stable passivating layer formed already during the first cycle.

Acknowledgement The authors greatly acknowledge a support by the EU programme Research Fund for Coal and Steel under contract number RFCR-CT-2005-00004.

\section{References}

1. C. Kim, T. Fujimo, T. Hayashi, M. Endo, M.S. Dresellhaus, Structural and electrochemical properties of pristine and B-doped materials for anode Li-ion secondary batteries, J. Electrochem. Soc. 147 (2000) 1265-1270.

2. M.H. Chen, G.T. Wu, G. M. Zhu, J.K. You, Z.G. Liu, Characterization and electrochemical investigation of boron-doped mesocarbon microbead anode materials for Li-ion batteries, J. Solid State Electrochem. 6 (2002) 420-427.

3. J. Machnikowski, E. Frackowiak, K. Kierzek, D. Waszak, R. Benoit, F. Béguin, Lithium insertion into boron containing carbons prepared by co-pyrolysis of coal-tar pitch and borane-pyridine complex, J. Phys. Chem. Solids 65 (2004) 153-158. 


\section{Figure captions}

Figure 1. Flow type anisotropy of antracene oil derived-pitch coke observed by optical microscopy.

Figure 2. Galvanostatic charge/discharge characteristics of graphitic carbon P-1-2900 H. Current load of $20 \mathrm{~mA} / \mathrm{g}$.

Figure 3. Galvanostatic charge/discharge characteristics of boronated graphitic carbon P-1-2900/B-2300 H. Current load of $20 \mathrm{~mA} / \mathrm{g}$. 


\section{Tables}

Table 1. Structural parameters of graphitic carbons and boronated graphitic carbons

\begin{tabular}{lcccc}
\hline Sample & $d_{002} \mathrm{~nm}$ & $L_{c} \mathrm{~nm}$ & $L_{a} \mathrm{~nm}$ & $L_{112} \mathrm{~nm}$ \\
\hline $\mathrm{P}-1-2300$ & 0.3385 & 33 & 52 & 4.2 \\
$\mathrm{P}-1-2300 \mathrm{~B}_{\mathrm{a}}$ & 0.3371 & 43 & 61 & 10.5 \\
$\mathrm{P}-1-2900$ & 0.3364 & 47 & 83 & 14.4 \\
$\mathrm{P}-1-2900 / \mathrm{B}_{\mathrm{c}}-2300$ & 0.3357 & 52 & 60 & 12.2 \\
$\mathrm{P}-1-2900 / \mathrm{B}_{4} \mathrm{C}-2300$ & 0.3357 & 47 & 52 & 11.8 \\
$\mathrm{P}-1-3100$ & 0.3366 & 56 & 94 & 17.1 \\
\hline
\end{tabular}


Figures

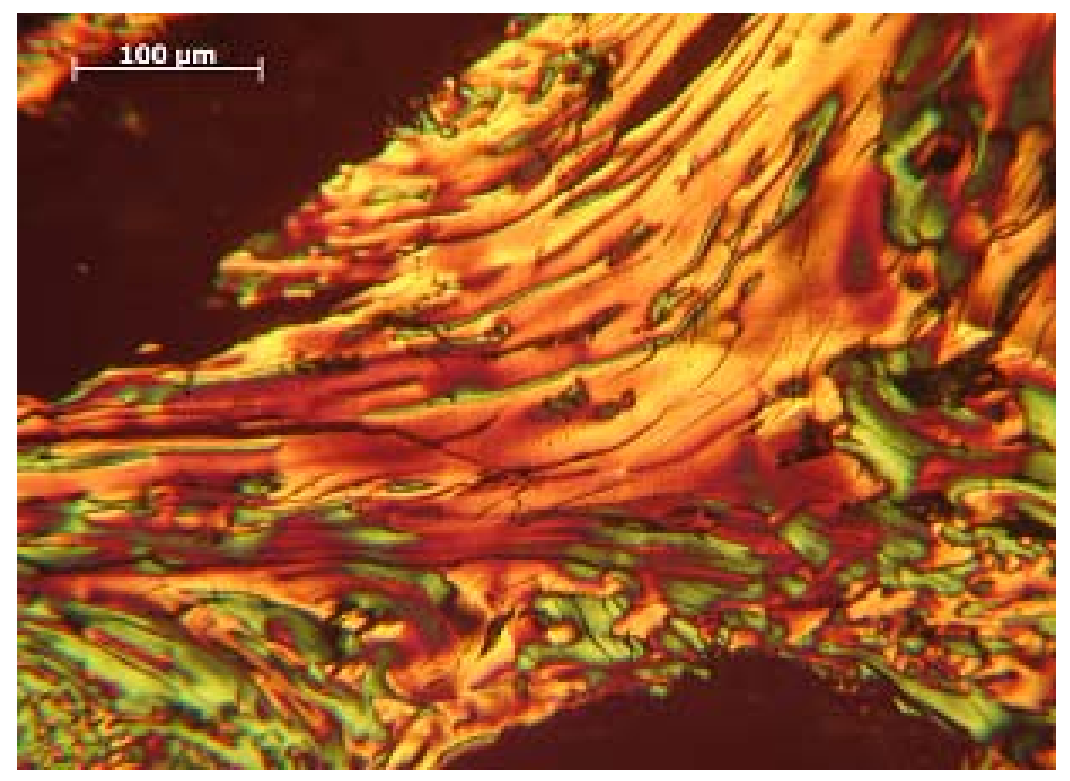

Fig. 1. Frackowiak, et al 


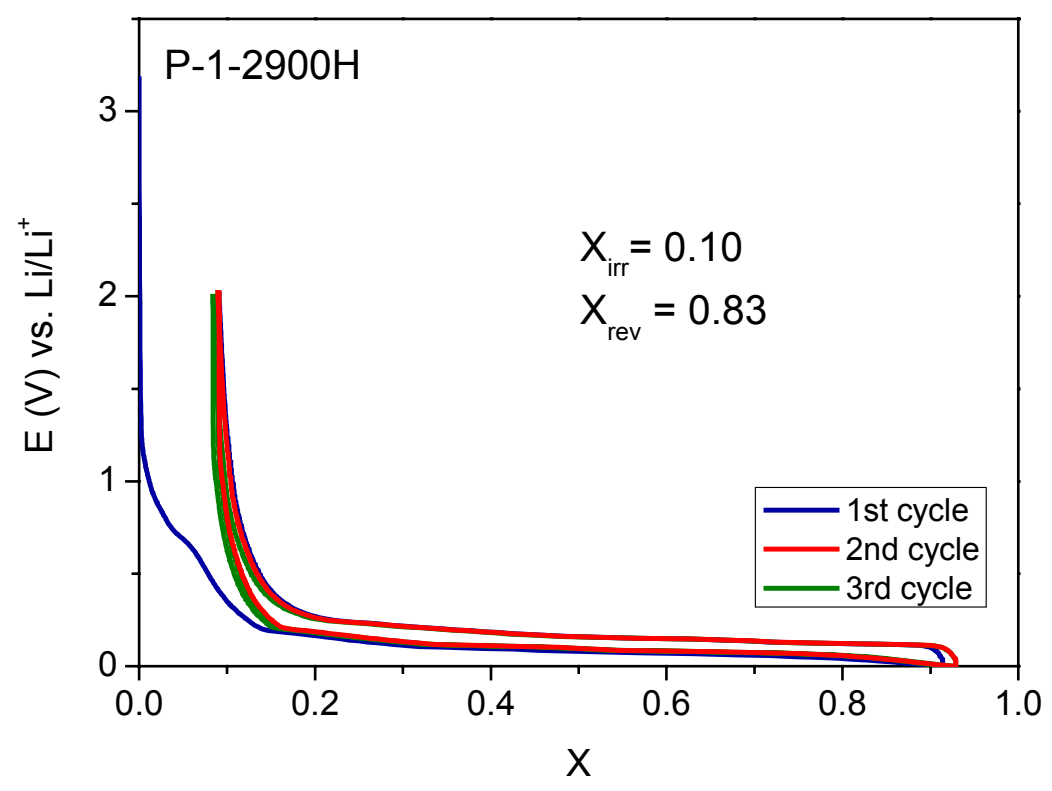

Fig. 2. Frackowiak, et al 


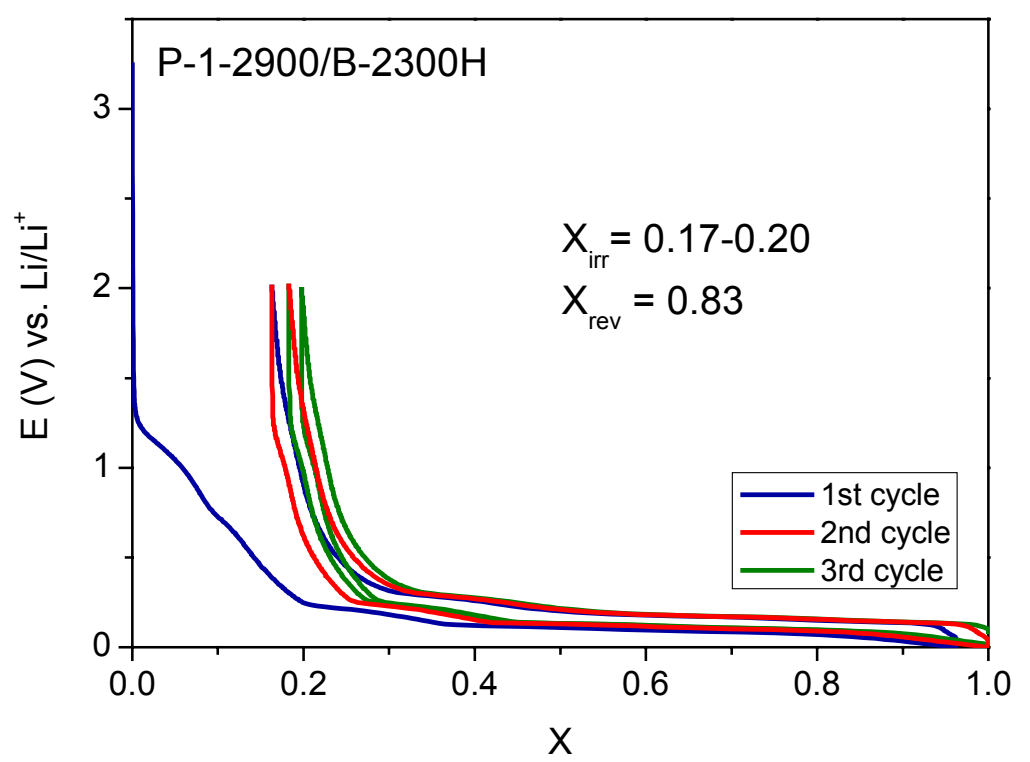

Fig. 3. Frackowiak, et al 